\title{
TRANSLATION TO PORTUGUESE LANGUAGE AND CROSS-CULTURAL ADAPTATION OF THE MODIFIED ROWE SCORE FOR OVERHEAD ATHLETES
}

Freddy Beretta Marcondes ${ }^{1}$, Rodrigo Antunes de Vasconcelos ${ }^{2}$, Adriano Marchetto ${ }^{3}$, André Luis Lugnani de Andrade ${ }^{4}$, Américo Zoppi Filho ${ }^{5}$, Maurício Etchebehere ${ }^{6}$

\begin{abstract}
Objetctive: Study was to translate and culturally adapt the modified Rowe score for overhead athletes. Methods: The translation and cultural adaptation process initially involved the stages of translation, synthesis, back-translation, and revision by the Translation Group. It was than created the pre-final version of the questionnaire, being the areas "function" and "pain" applied to 20 athletes that perform overhead movements and that suffered SLAP lesions in the dominant shoulder and the areas "active compression test and anterior apprehension test" and "motion"
\end{abstract}

were applied to 15 health professionals. Results: During the translation process there were made little modifications in the questionnaire in order to adapt it to Brazilian culture, without changing the semantics and the idiomatic concept originally described. Conclusion: The questionnaire was easily understood by the subjects of the study, being possible to obtain the Brazilian version of the modified Rowe score for overhead athletes that underwent surgical treatment of the SLAP lesion.

Keywords - Validation Studies; Atlhetic Injuries; Shoulder

\section{INTRODUCTION}

Superior labral lesions are common in the athletic population, especially in athletes who perform throwing movements. The first description of labral lesions in the upper region of the glenoid was made by Andrews et $\mathrm{al}^{(1)}$ and later described by Snyder et $\mathrm{al}^{(2)}$ with the term SLAP (superior labrum anterior and posterior), characterized by a partial avulsion of the glenoid labrum in its superior aspect starting posteriorly and extending anteriorly, possibly affecting the insertion of the long head of the biceps. Such lesions are characterized by pain and instability that affect the performance of athletes ${ }^{(3)}$. Funk and Snow ${ }^{(4)}$ evaluated the SLAP lesions in 51 rugby players, diagnosed by arthroscopy, noting an incidence of $35 \%$ in the population studied. Similarly, Kampa and Clasper ${ }^{(5)}$ observed a $38.6 \%$ incidence of SLAP lesions in the military population of the United States.

Although the mechanism of injury is still not entirely clear, there are currently two theories: 1) falls on the upper limb with the shoulder in abduction and flexion, resulting in the impingement of the humeral head against the insertion of the biceps and superior labrum $^{(2)}$ and 2) injuries resulting from repetitive throwing activities in which twisting forces occur at the insertion of the long head of the biceps when the shoulder is in abduction and maximum external rotation, a mechanism described by Burkhart and Mor$\operatorname{gan}^{(6)}$ as "peel-back."

The treatment of SLAP lesions is essentially surgical, especially in young people and athletes due to glenohumeral instability acquired and concomitant

1 - Master's degree student in Science of Surgery, Unicamp. Wilson Mello Institute - Campinas, SP, Brazil.

2 - Doctor's degree in Medical Sciences, FMRP - USP. Wilson Mello Institute - Campinas, SP, Brazil.

3 - Master's degree in Orthopedics and Traumatology, USP. Wilson Mello Institute - Campinas, SP, Brazil.

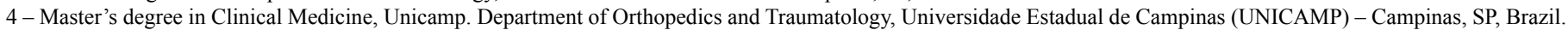

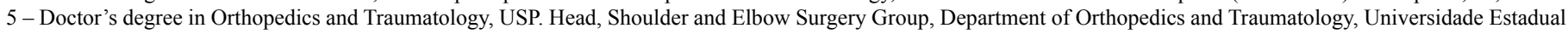
de Campinas (Unicamp) - Campinas, SP, Brazil.

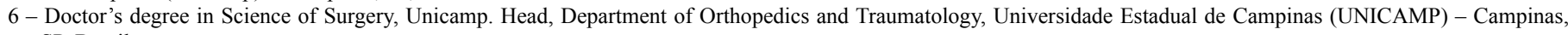
SP, Brazil.

Study conducted at the Department of Orthopedics and Traumatology, Unicamp, Campinas, SP.

Correspondence: Av. José Rocha Bonfim, 214, Ed. Chicago, $1^{\text {o }}$ andar, Condomínio Praça Capital - 13080-650 - Campinas, SP, Brazil. Email: freddy@iwmello.com.br Received for publication: 8/22/2011, accepted for publication: 10/4/2011.

The authors declare that there was no conflict of interest in conducting this work 
rotator cuff ruptures ${ }^{(7)}$. In order to have an objective evaluation of the athlete undergoing surgical treatment of the SLAP lesion, specific questionnaires are needed to quantify pre- and post-treatment functional outcomes. There are several questionnaires in the literature for the functional assessment of the shoulder. A systematic review of Bot et $\mathrm{al}^{(8)}$ shows 16 questionnaires for this purpose in the English literature and yet only six questionnaires have version available for use in Brazil, but none of these are used to specifically assess functional outcomes in overhead athletes with a SLAPtype lesion.

Aiming to evaluate functional results postoperatively, Ide et al $^{(9)}$ developed a questionnaire modified from the original Rowe score ${ }^{(10)}$, but to be applied to overhead athletes. This modified Rowe questionnaire has a score from 0 to 100 points and is divided into four areas, namely: 1) 50 points for function; 2) 30 points for the active compression test and the anterior apprehension test; 3) 10 points for pain; 4) 10 points for mobility. The results were classified as excellent between 90 and 100 points, good between 70 and 89 points, fair between 40 and 69 points, and poor when below 40 points.

Given the absence of questionnaires in Portuguese to evaluate the results of treatment of overhead athletes with SLAP-type lesions, the objective of this study was to translate and culturally adapt the modified Rowe questionnaire for use in athletes so that it can be used reliably in Brazil.

\section{MATERIALS AND METHODS}

The process of translating and culturally adapting the modified Rowe questionnaire to athletes followed the methodological criteria described by Beaton et $\mathrm{al}^{(11)}$ used by the American Academy of Orthopaedic Surgeons (AAOS) and the International Quality of Life Assessment (IQOLA). Prior to the beginning of the translation, the authors of the original version of the modified Rowe questionnaire for athletes ${ }^{(9)}$ authorized the process and the project was started. This study was approved by the Research Ethics Committee of the Universidade Estadual de Campinas, under case No. 493/2010. All participants signed an informed consent form and their identities were kept confidential.

The process of translation and cultural adaptation involved six steps: 1) translation, 2) synthesis, 3) back-translation, 4) review by the translation group, 5) pre-test, and 6) evaluation of documents by the translation group. In the first stage, the modified Rowe questionnaire was translated into Portuguese by two independent certified and bilingual translators, who had Portuguese as their mother tongue and were fluent in English, one of whom had knowledge in the field of health and awareness of the purpose of the study and the other did not. Versions T1 and T2 were then created and, in the second stage of synthesis, were analyzed with the original questionnaire in a meeting between the investigators and the initial translators, leading to version T3.

In the next stage of back-translation, the T3 version was translated back into English by two other bilingual translators (B1 and B2), whose mother tongue was English, and who were fluent in Portuguese and living in Brazil. The translators responsible for the back-translation did not work in healthcare and therefore had no knowledge of the original questionnaire in English ${ }^{(12)}$.

In the fourth stage, all versions (original, $\mathrm{T} 1, \mathrm{~T} 2$, T3, B1, and B2) were reviewed by the translation group, consisting of two orthopedic doctors (one a specialist in shoulder surgery), two physiotherapists and the translators involved in the process, which consolidated all versions of the questionnaire and developed the pre-final version of the modified Rowe questionnaire.

In the fifth stage, two pre-tests of the pre-final version of the questionnaire were created in order to eliminate any items that were not understood. The "function" and "pain" domains were used on 20 patients and the "active compression test and anterior apprehension test" and "mobility" domains were used on 15 health professionals (two rheumatologists, four orthopedic physicians, four residents in orthopedics, and five physiotherapists working in traumatology and orthopedics). Only the "function" and "pain" domains were used on patients because the "active compression test and anterior apprehension test" and "mobility" domains include items of the clinical assessment performed by the examiner.

All subjects selected for the study were recruited voluntarily in the orthopedics and traumatology department of a university hospital in a public institution. Inclusion criteria were defined as: 1) professional 
or recreational athletes of sports in which there are throwing movements, 2) a positive O'Brien's test ${ }^{(13)}$, 3) SLAP lesion confirmed by arthrography ${ }^{(14)}$. Subjects who had rheumatic or neurological diseases or previous fractures of any part of the humerus were excluded from the study. Table 1 describes the demographics of the subjects participating in the study.

The study authors decided to use the questionnaire in an interview format so that they did not exclude patients with visual problems, such as disabled athletes. After answering the pre-final version, each patient was interviewed by a researcher on their understanding of each question. The questions that were not understood by over $15 \%$ of patients or health professionals were reformulated by the translation group to make the necessary changes.

The final stage consisted of sending the Brazilian version of the Rowe questionnaire to the developers of the instrument and the translation group for approval of the process of translation and cultural adaptation.

Table 1 - Demographic data for the subjects of the study.

\begin{tabular}{|c|c|}
\hline Characteristics & \\
\hline $\mathrm{Age}^{\alpha}$ & $28.71 \pm(6.5)$ \\
\hline \multicolumn{2}{|l|}{$\operatorname{Sex}^{\beta}$} \\
\hline Male & $75 \%(15)$ \\
\hline Female & $25 \%(5)$ \\
\hline Duration of symptoms (months) ${ }^{\alpha}$ & $20.65 \pm(12.2)$ \\
\hline \multicolumn{2}{|l|}{ Education level $^{\beta}$} \\
\hline Illiterate & $0 \%(0)$ \\
\hline Elementary school & $20 \%(4)$ \\
\hline High School & $45 \%(9)$ \\
\hline Higher education & $35 \%(7)$ \\
\hline \multicolumn{2}{|l|}{ Sport $^{\beta}$} \\
\hline Tennis & $25 \%(5)$ \\
\hline Handball & $25 \%(5)$ \\
\hline Swimming & $15 \%(3)$ \\
\hline Baseball & $15 \%(3)$ \\
\hline Soccer (goalie) & $5 \%(1)$ \\
\hline Volleyball & $15 \%(3)$ \\
\hline
\end{tabular}

Data described as mean \pm (standard deviation)

\section{RESULTS}

After the questionnaire was translated by two translators, there was a translation group meeting in which the similarities between translations were observed, with minor differences found in the second, third, and fourth items of the "function" domain (Table 2).

Also during the synthesis phase, a small change was made to the questionnaire at the discretion of the translation group in the second item of the "mobility" domain in the phrase "as much as $25 \%$ loss of motion in any plane" was translated by the first translator as "tanto quanto $25 \%$ de perda da mobilidade em qualquer plano" (as much as $25 \%$ loss of motion in any plane) and the second translator as "em torno de $25 \%$ de perda da mobilidade em qualquer plano" (around 25\% loss of motion in any plane). The translation group decided that the phrase should be "aproximadamente $25 \%$ de perda da mobilidade em qualquer plano" (approximately 25\% loss of motion in any plane), so as to be more easily understood by the patient and the evaluator. Another change that was made at the discretion of the translation group was to change the word "football" (which originally refers to an American football) for "soccer ball", since football is not known by the majority of Brazilians and soccer is the most popular sport in Brazil. Both changes were accepted by the authors of the original version. Thus, the translation group defined the synthesized version of the questionnaire and it went through the process of back-translation, in which there was great similarity between both back-translated and equivalent versions to the original version of the modified Rowe questionnaire for athletes, except in the second item of the mobility domain that was back-translated as "about $25 \%$ loss of motion in any plane."

After reviewing all versions of translation and backtranslation, the pre-test phase was initiated, in which the "function" and "pain" domains were used on 20 patients and the "active compression test and anterior apprehension test "and" mobility " domains were used on 15 health professionals. In this phase, a 15\% index of misunderstanding was not observed on any item in the questionnaire, whether by patients or healthcare professionals, demonstrating that the Brazilian version of the modified Rowe for athletes is easy to understand and was appropriately culturally adapted.

\section{DISCUSSION}

Several questionnaires have been translated and culturally adapted to the Portuguese language in order to evaluate the functionality of the shoulder in various impairments ${ }^{(15-17)}$. However, none of these questionnaires specifically evaluates athletes performing a throwing motion in their sports activities with SLAP-type lesions. The Rowe questionnaire adapted for athletes exists for this purpose, created by Ide et $\mathrm{al}^{(9)}$, but which had not yet been translated 
Table 2 - Changes in the translation and synthesis phase of the modified Rowe questionnaire.

\begin{tabular}{c|c|c|c|c}
\hline Item (domain) & Original version & Translator 1 & Translator 2 & Synthesis \\
\hline $2^{\text {nd }}$ (function) & $\begin{array}{c}\text { No limitation in work; } \\
\text { slight limitation in throwing } \\
\text { baseball }[\ldots]\end{array}$ & $\begin{array}{c}\text { Sem limitações no trabalho; } \\
\text { leve limitação ao arremessar } \\
\text { uma bola de beisebol }[\ldots]\end{array}$ & $\begin{array}{c}\text { Sem limitações no trabalho; } \\
\text { ligeira limitação em arremessar } \\
\text { uma bola de beisebol }[\ldots]\end{array}$ & $\begin{array}{c}\text { Sem limitações no trabalho; } \\
\text { leve limitação ao arremessar } \\
\text { uma bola de beisebol }[\ldots]\end{array}$ \\
\hline $3^{\text {rd }}$ (function) & $\begin{array}{c}\text { Moderate limitation in } \\
\text { overhead work, }[\ldots]\end{array}$ & $\begin{array}{c}\text { Limitação moderada no } \\
\text { trabalho com o braço por cima } \\
\text { da cabeça, }[\ldots]\end{array}$ & $\begin{array}{c}\text { Limitação moderada no trabalho } \\
\text { com o braço acima do nível da } \\
\text { cabeça, }[\ldots]\end{array}$ & $\begin{array}{c}\text { Limitação moderada no } \\
\text { trabalho com o braço acima } \\
\text { do nível da cabeça, }[\ldots]\end{array}$ \\
\hline $4^{\text {th }}$ (function) & $\begin{array}{c}{[\ldots] \text { unable to work }} \\
\text { overhead. }\end{array}$ & $\begin{array}{c}{[\ldots] \text { incapaz de trabalhar com o o o }} \\
\text { braço por cima da cabeça. }\end{array}$ & $\begin{array}{c}{[\ldots] \text { incapaz de trabalhar com o }} \\
\text { braço acima do nível da cabeça. }\end{array}$ & $\begin{array}{c}{[\ldots] \text { incapaz de trabalhar com }} \\
\text { o braço acima do nível da } \\
\text { cabeça. }\end{array}$ \\
\hline $2^{\text {nd }}$ (mobility) & $\begin{array}{c}\text { As much as 25\% loss of } \\
\text { motion in any plane. }\end{array}$ & $\begin{array}{c}\text { Tanto quanto 25\% de perda da da } \\
\text { mobilidade em qualquer plano. }\end{array}$ & $\begin{array}{c}\text { Em torno de 25\% de perda da } \\
\text { mobilidade em qualquer plano. }\end{array}$ & $\begin{array}{c}\text { Aproximadamente 25\% de } \\
\text { perda da mobilidade em } \\
\text { qualquer plano. }\end{array}$ \\
\hline
\end{tabular}

and culturally adapted for use in Brazil. The Brazilian version of the modified Rowe questionnaire for athletes was obtained after a careful process of translation and cultural adaptation described by Beaton et al. ${ }^{(11)}$ and Guillemin et al ${ }^{(12)}$, trying to conceptually and semantically preserve as much as possible from the originally published language.

During the synthesis phase, two changes were made in the questionnaire: 1) the phrase "as much as $25 \%$ loss of motion in any plane," which was translated as "as much as $25 \%$ loss of mobility in any plane," was modified in the Portuguese version to "approximately $25 \%$ loss of mobility in any plane"; 2 ) the word "football" was translated as "soccer ball", as soccer is the most popular sport in Brazil, making the questionnaire easy to understand. When one reads in the questionnaire "throw a soccer ball," one understands a throw as that performed with both arms above the head or, in the case of goalkeepers, throwing the ball to put it back into play. Although baseball is not a popular sport in Brazil, the questions related to this sport were kept, since $15 \%$ of our sample played baseball.

On the first application of the questionnaire to the 35 study subjects (20 athletes and 15 health professionals), rates of incomprehension below 15\% were observed on all items, demonstrating that the cultural adaptation of the questionnaire was complete, with no need for a second pre-test phase. This fact can be explained by the simple and objective characteristic of the original questionnaire, making this instrument easily understood by both the athlete being assessed and the health professional who is evaluating. Obviously, the professional who uses the modified Rowe questionnaire must work in the field of traumatology and orthopedics, as there are specific tests to be performed and which have great importance in the final score of the questionnaire.

The study authors also chose to administer the questionnaire as an interview so that disabled blind athletes would not be excluded, for example. Moreover, the number of subjects used in our study was similar to other studies of translation and cultural adaptation of questionnaires to assess shoulder function, such as the study of Knaut et al ${ }^{(16)}$ showing that our study sample was sufficient to conclude the translation and cultural adaptation of the modified Rowe questionnaire. The translation and adaptation of the modified Rowe questionnaire for overhead athletes may be of great use to doctors and physiotherapists, both in the clinic and in research, given the high incidence of shoulder girdle disorders in Brazilian athletes who perform throwing motions, such as swimmers ${ }^{(18)}$. This questionnaire makes it possible to monitor the results of surgical repair of SLAP-type lesions in overhead athletes, because this instrument has questions specifically regarding sports activities related to the throwing motion, making the functional evaluation more precise.

After a careful and detailed process of translation and cultural adaptation, it was possible to obtain the Brazilian version of the modified Rowe questionnaire for overhead athletes (Appendix 1). Instruments developed in foreign languages must pass this rigorous process for use in countries with different sociocultural characteristics. Despite the conclusion of the Brazilian version of the questionnaire, the authors of this study continue their research in order to analyze the psychometric variability of the modified Rowe questionnaire for overhead athletes. 


\section{REFERENCES}

1. Andrews JR, Carson WG Jr, McLeod WD. Glenoid labrum tears related to the long head of the biceps. Am J Sports Med. 1985;13(5):337-41.

2. Snyder SJ, Karzel RP, Del Pizzo W, Ferkel RD, Friedman MJ. SLAP lesions of the shoulder. Arthroscopy. 1990;6(4):274-9.

3. Andrews JR, Carson WG Jr, McLeod WD. Glenoid labrum tears related to the long head of the biceps. Am J Sports Med. 1985;13(5):337-41.

4. Funk L, Snow M. SLAP tears of the glenoid labrum in contact athletes. Clin J Sport Med. 2007;17(1):1-4.

5. Kampa RJ, Clasper J. Incidence of SLAP lesions in a military population. J R Army Med Corps. 2005;151(3):171-5.

6. Burkhart SS, Morgan CD. The peel-back mechanism: its role in producing and extending posterior type II SLAP lesions and its effect on SLAP repair rehabilitation. Arthroscopy. 1998;14(6):637-40.

7. Dodson CC, Altchek DW. SLAP lesions: an update on recognition and treatment. J Orthop Sports Phys Ther. 2009;39(2):71-80.

8. Bot SD, Terwee CB, van der Windt DA, Bouter LM, Dekker J, de Vet HC. Clinimetric evaluation of shoulder disability questionnaires: a systematic review of the literature. Ann Rheum Dis. 2004;63(4):335-41.

9. Ide J, Maeda S, Takagi K. Sports activity after arthroscopic superior labra repair using suture anchors in overhead-throwing athletes. Am J Sports Med. 2005;33(4):507-14

10. Rowe CR, Patel D, Southmayd WW. The Bankart procedure: a long-term end-result study. J Bone Joint Surg Am. 1978;60(1):1-16.
11. Beaton DE, Bombardier C, Guillemin F, Ferraz MB. Guidelines for the process of cross-cultural adaptation of self-report measures. Spine (Phila Pa 1976). 2000;25(24):3186-91.

12. Guillemin F, Bombardier C, Beaton D. Cross-cultural adaptation of health-related quality of life measures: literature review and proposed guidelines. $J$ Clin Epidemiol. 1993;46(12):1417-32.

13. O'Brien SJ, Pagnani MJ, Fealy S, McGlynn SR, Wilson JB. The active compression test: a new and effective test for diagnosing labral tears and acromioclavicular joint abnormality. Am J Sports Med. 1998;26(5):610-3.

14. Bencardino JT, Beltran J, Rosenberg ZS, Rokito A, Schmahmann S, Mota J, et al. Superior labrum anterior-posterior lesions: diagnosis with MR arthrography of the shoulder. Radiology. 2000;214(1):267-71.

15. Lopes AD, Stadniky SP, Masiero D, carrera EF, Ciconelli RM, Griffin S. Tradução e adaptação cultural do WORC: um questionário de qualidade de vida para alterações do manguito rotador. Rev Bras Fisioter. 2006;10:309-15.

16. Knaut LA, Moser ADL, Melo SA, Richards RR. Tradução e adaptação cultural à língua portuguesa do American Shoulder and Elbow Surgeons Standardized Shoulder Assessment Form (ASES) para avaliação da função do ombro. Rev Bras Reumatol. 2010;50(2):176-89.

17. Martins J, Napoles BV, Hoffman CB, Oliveira AS. The Brazilian version of Shoulder Pain and Disability Index: translation, cultural adaptation and reliability. Rev Bras Fisioter. 2010;14(6):527-36.

18. Santana EP, Ferreira BC, Ribeiro G. Associação entre discinesia escapular e dor no ombro de praticantes de natação. Rev Bras Med Esporte. 2009;15(5):342-46.

Appendix 1 - Rowe questionnaire modified to assess overhead athletes with SLAP-type lesion.

\begin{tabular}{|l|c|}
\hline \multicolumn{1}{|c|}{ Categoria } & Pontos \\
\hline Função - 50 pontos & 50 \\
\hline $\begin{array}{l}\text { Sem limitações no esporte ou trabalho; capaz de arremessar uma bola de beisebol ou futebol } \\
\text { Sem limitação no trabalho; leve limitação ao arremessar uma bola de beisebol, sacando forte no tênis; pode arremessar uma } \\
\text { bola de futebol normalmente }\end{array}$ & 35 \\
\hline $\begin{array}{l}\text { Limitação moderada no trabalho com o braço acima do nível da cabeça, arremessando uma bola de beisebol ou futebol, ou } \\
\text { sacando forte no tênis }\end{array}$ & 20 \\
\hline Limitação marcada no arremesso e em todos os esportes; incapaz de trabalhar com o braço acima do nível da cabeça & 0 \\
\hline Dor - 10 pontos & 10 \\
\hline Nenhuma & 5 \\
\hline Moderada & 0 \\
\hline Severa & 30 \\
\hline Teste de compressão ativa e teste de apreensão anterior - 30 pontos & 15 \\
\hline Resultado negativo & 0 \\
\hline Resultado negativo, mas dor com o braço na posição de abdução e rotação externa & \\
\hline Teste de compressão ativa positivo ou teste de apreensão anterior positivo & 10 \\
\hline Mobilidade - 10 pontos & 5 \\
\hline Amplitude de movimento completa & 0 \\
\hline Aproximadamente 25\% de perda da mobilidade em qualquer plano & \\
\hline Mais que 25\% de perda da mobilidade em qualquer plano & \\
\hline
\end{tabular}

